\title{
Simboličke i značenjske funkcije flore u Pričama iz davnine Ivane Brlić-Mažuranić
}

Vanda Babić*

vbg109@gmail.com,vbabic@unizd.hr

Denis Vekić**

dvekic@unizd.hr https://doi.org/10.31192/np.16.2.4

UDK: 58:821.163.42-34

821.163.42Brlić-Mažuranić, I.

Izvorni znanstveni rad / Original scientific paper

Primljeno: 12. ožujka 2018.

Prihvaćeno: 24. travnja 2018.

Tekstovi s elementima mitskog jezika često su oni u kojima se nalaze simboličke vrijednosti te prenesena i prikrivena značenja svega što se naoko čini sasvim obično i svakodnevno. Motivima u umjetničkim i narodnim bajkama svojstvena je plošnost izričaja, no u njihovoj selektivnoj uporabi često se kriju vrijednosti $i$ značenja koja se mogu protumačiti detaljnijim istraživanjem i razumijevanjem značenjskog konteksta stvaranja bajke. Ovaj rad polazi od ideje da se autorica Priča iz davnine u svojim bajkama služila motivskim i značenjskim spektrom koji se aplicira na floru u slavenskoj mitologiji. Korištenje pojedinih primjera flore nosi simboličke i značenjske funkcije koje se mogu detektirati proučavanjem korpusa mitskih motiva i elemenata koji su se baštinili u slavenskoj mitologiji $i$ etnobotanici.

Ključne riječi: flora, simboli, Priče iz davnine, motivi, analiza.

\section{Uvod}

Pristupanje proučavanju književnoumjetničkog djela iz kojeg se analizira jedan gradbeni element zahtijeva posvećenost podjednako pojedinosti koliko i cjelini. Već do sada su utvrđene dimenzije intertekstualnih dodira s mitološkohistoriografskim diskursom ${ }^{1} \mathrm{u}$ djelu Priče iz davnine te se na tragu tih dodira u

\footnotetext{
* Prof. dr. sc. Vanda Babić, Odjel za kroatistiku i slavistiku Sveučilišta u Zadru, Obala kralja Petra Krešimira IV., br. 2, HR-23000 Zadar.

**Dr. sc. Denis Vekić, Odjel za kroatistiku i slavistiku Sveučilišta u Zadru, Obala kralja Petra Krešimira IV., br. 2, HR-23000 Zadar.

${ }^{1}$ Usp. Tihomir ENGLER, Andrijana KOS-LAJTMAN, Bajkopisna diseminacija mitoloških motiva u Pričama iz davnine Ivane Brlić-Mažuranić na primjeru intertekstualnih poveznica $\mathrm{s}$ leksikonom A. Tkanyja, Studia mythologica Slavica, 14 (2011) 305-324, 305.
} 
ovom radu pozornost usmjerava na aspekt pojavnosti flore kao mogućem simboličkom konstruktu bajke. Pri tom se mora uzeti u obzir da je izvorno prvo izdanje imalo šest bajki kojima su tek kasnije pridodane bajke Lutonjica Toporko $i$ devet župančića te Jagor. U ovom radu će se pozornost usmjeriti upravo na njih osam. Proučavanje smisla, značaja i simboličkih vrijednosti pojavnosti stabala i biljaka u ovom djelu postavlja metodološki problem budući da ni samo djelo nije podjednako usmjereno na simboličke i značenjske vrijednosti botanike u svojih osam bajki. Nepostojanje simboličke konstante u predočavanju pojavnosti vrste drveća i biljaka, kao ni ravnomjerna kvantitativna uporaba tih motiva upućuje na epizodnost samog djela koje je podijeljeno u stupnjevitim odnosima mitološkog, etnološkog i usmenoknjiževnog. Naravno, takva podjela nije posve primjenjiva na sve bajke, ali je simbolička funkcija flore u bajkama u skladu i logici kreiranja novih bajki čiji svijet i priroda počivaju na temeljima etnobotaničkih vjerovanja slavenskih naroda, ali i šire, Indoeuropljana. Točna lokacija i vrijeme radnje u bajkama nije precizirano, a opet, odabir specifičnih biljaka i stabala u Pričama iz davnine ocrtava osnovne kulturno-prostorne osobine pomoću kojih se može reći da prostor u kojem se odvijaju radnje bajki ovog djela pripada europskom vegetacijskom spektru.

Djeca već u ranoj dobi usvajaju koncept kulture kojoj pripadaju kroz vizualne simbole koji se očituju na više razina. Razumjevši vizualne simbole prostora koji ih okružuje mogu percipirati prostorne i kulturološke razlike kada se s njima suoče. ${ }^{2}$ Svijet Priča iz davnine, u vegetacijskom smislu je svijet koji je djeci vrlo poznat $i$ koji ih svakodnevno okružuje. Biljke i stabla koje Ivana BrlićMažuranić spominje u Pričama iz davnine nisu egzotičnog podrijetla nego su jako česti u prostornoj vizuri cjelokupne Hrvatske, ali i šireg prostora europskog konteksta. Osim toga, i sama je autorica istaknula privrženost prirodi, a posebno prema krajevima i lokalitetima kao što su Varaždinski brijeg, okolica Slavonskog Broda, planina Klek i rijeka Dobra. U sjećanjima na navedene lokacije autorica se osvrće na ljepotu prirode i folklor. ${ }^{3} \gg$ Radnja bajki u ovom djelu nije ni povijesno ni zemljopisno lokalizirana, ali je smještena u sekundarne svjetove $\ll^{4}$ koji vegetacijski nisu strani svjetovi nego poznati prostori gdje se priroda manifestira kroz poznate botaničke obrise.

${ }^{2}$ Usp. Janelle MATHIS, The Significance of the Arts in Culture. Learning through Children's Literature, Libri E liberi - časopis za istraživanje dječje književnosti i kulture, 4 (2015) 85-102, 86.

${ }^{3}$ Usp. Andrijana KOS-LAJTMAN, Tamara TURZA-BOGDAN, Utjecaj usmenoknjiževnog i mitološkog supstrata varaždinskog kraja na književni rad Ivane Brlić-Mažuranić, Narodna umjetnost -hrvatski časopis za etnologiju i folkloristiku, 47 (2010) 2, 175-190, 179.

${ }^{4}$ Kristina GIACOMETTI, Od čudesnoga do fantastičnoga. Dimenzije svjetova Ivane BrlićMažuranić i Nade Iveljić, u: Berislav MAJHUT, Smiljana NARANČIĆ KOVAČ, Sanja LOVRIĆ KRALJ (ur.), Šegrt Hlapić od čudnovatog do čudesnog. Zbornik radova Međunarodne znanstvene konferencije »Od čudnovatog do čudesnog«, Zagreb, Slavonski Brod, 2013., Zagreb - Slavonski Brod, Hrvatska udruga istraživača dječje književnosti, Ogranak Matice hrvatske Slavonski Brod, 2015, 697-708, 706. 
Proučavajući pojavnost i spominjanje drveća i biljaka u Pričama iz davnine uočava se da kvantitet i simbolička vrijednost ovise o stupnju mitološke insinuacije, prostorno logičkim odabirom pojavnosti pojedine biljke, te etnokulturnom tradicijskom vjerovanju o pojedinom drveću i nižem raslinju.

Etnobotaničke vrijednosti u ovom djelu variraju te se mogu pronaći mitološke kategorije vjerovanja, kao što je primjer u Šumi Striborovoj; kategorije tradicijskog vjerovanja, kao što je slučaj u Lutonjici Toporku i devet župančića; te etno-agrarni aspekt koji je vidljiv u malim dijelovima većine bajki u Pričama iz davnine.

No, da bi se svi ovi elementi uočili i adekvatno proučili, metodološki će se obrađivati bajke u redoslijedu kojim se pojavljuju u Pričama iz davnine.

\section{Kako je Potjeh tražio istinu}

Već u prvim rečenicama ove umjetničke bajke spominje se bukva, i to u kontekstu stare bukove gore. Osim u ovoj bajci, nalazimo je u bajci Lutonjica Toporko $i$ devet župančića, no ne javlja se pojedinačno stablo već bukovik, čime se pojavnost stabla bukve ovdje stavlja na razinu šume od bukova stabla. U oba bukovika živjele su slične osobe po svom opisu i suživotu s drugim pojedincima. Primjerice, u Potjehu, starac Vjest živi u bukovoj gori s tri unuka, dok u Lutonjici Toporku u bukoviku boravi djed Neumijka s osam dječaka koje poučava sedam mudrosti. Bukova gora i bukovik na gori mjesta su obitavanja starih mudrih djedova i njihovih »učenika« i sljedovatelja. Ta činjenica o poučavanju mudrosti može možda imati vezu s upotrebom bukove kore kao sredstva za pisanje, a time i nastajanje tekstova iz kojih se može poučavati. Tradicijsko povezivanje stabla bukve s pisanjem ${ }^{5}$ vidljiv je u korištenju germanske osnove "bōk koja se osim u slavenskim jezicima, gdje se navodi kao "bukŭ, javlja i u gotskom, engleskom i njemačkom jeziku. ${ }^{6}$ Pretpostavljena poveznica može biti značajna, no ne bi ju se trebalo doslovno shvatiti ni interpretirati kao autoričin pokušaj impliciranja poučavanja sa starijih na mlađe generacije, budući da je takvo djelovanje već izraženo u samim bajkama. Osim ovog spominjanja bukve, među granama stare bukve $e^{7}$ se skrio i Bjesomar, vladar šumskih bjesova. Logično je, prema prostornoj logici ove bajke, da u bukoviku Bjesomar bude skriven granama bukve, no ovdje se može primijetiti da je skrivanje Bjesomara upravo tim granama svojstvenije pučkom vjerovanju koje pripovijeda o šupljoj bukvi u kojoj žive vragovi. ${ }^{8}$ Treba se istaknu-

${ }_{5}^{5}$ Usp. Nikola VISKOVIĆ, Stablo i čovjek. Prilog kulturnoj botanici, Zagreb, Antibarbarus, 2001, 372.

${ }^{6}$ Usp. Tomo VINŠĆAK, Vjerovanja o drveću u Hrvata u kontekstu slavističkih istraživanja, Jastrebarsko, Naklada Slap, 2002, 89.

7 Usp. Vinko BREŠIĆ (ur.), Sabrana djela Ivane Brlić Mažuranić, kritičko izdanje, sv. 3: Bajke i basne, Slavonski Brod, Ogranak Matice hrvatske Slavonski Brod, 2011, 15.

${ }^{8}$ Usp. Vinšćak, nav. dj., 90. 
ti opreka svetog i nesvetog prostora kojeg navodi Suzana Marjanić kada opisuje svetost bukove gore. ${ }^{9}$ Tu navodi opreku između svetog prostora bukovika u kojem obitava starac Vjest i mjesta gdje raste rakita, gdje obitavaju Bjesomar i bjesovi. No, i ta slika je samo aluzija na poveznicu zlih nadnaravnih bića s bukvom i to ne znači da je moguće sliku skrivanja Bjesomara opravdati preuzimanjem vjerovanja o određenim stablima iz narodne tradicije.

Osim bukve, u ovoj se bajci od stabala i bilja spominju još brezova grana, mali grabići, tanani javori, divlja jabuka i bazga, rakita, ljuta trava i mahovina. Svi ovi navodi opisuju raznovrsnost flore te im se posebno ne pridaje pozornost $\mathrm{u}$ tekstu ni objašnjenjem ni funkcijom već se navode kao dijelovi flore koja okružuje svijet Potjeha. U etnografskom smislu, mali grab i tanki javorovi služe u bajci Ljutiši da od njih izradi junački pribor i oružje da bi zavladao svijetom. Iz tog podatka se vidi primjena i korištenje vrste drveta za proizvodnju određenih predmeta. U tom smislu je prikazana kao sirovina za obrtničko djelovanje u kojem se proizvode pribor i oružje. Divlja jabuka je stablo ispod kojeg Potjeh dolazi prileći i u njegovoj blizini ostaje neko vrijeme da bi se domislio istini. Stablo divlje jabuke je tako povezano s aktivnom Potjehovom misaonom potragom za istinom te predstavlja mjesto gdje Potjeh koristi umne vještine prisjećanja te je moguće pronaći kršćansku tradicijsku poveznicu s Potjehovim promišljanjem o istini ispod divlje jabuke. Jabuka je u kontekstu legendarija kršćanske mitologije često povezana sa spoznajom i otkrićem saznanja, iako je u kanonskom tekstu Biblije spomenut samo plod stabla, no ne i da je taj plod upravo plod jabuke. Zanimljivo je da u latinskom jeziku riječ malum ujedno označava jabuku i zlo. Zbog toga se u kršćanskoj povijesti razvila legenda da je stablo spoznaje dobra i zla upravo stablo jabuke..$^{10}$ Dok Potjeh umuje pod jabukom napastuje ga Bijes koji ga ometa u spoznaji te se u tom smislu napastovanje ispod stabla jabuke srednjovjekovnog kršćanskog legendarija može promatrati $\mathrm{u}$ alegorijskom smislu. No i taj prizor ne daje podjednake motivske cjeline koje bi se mogle uspješno povezati u kontekstu potpune alegorije $s$ kršćanskim legendarijem. Riječ je o fragmentiranim alegorijskim kategorijama koje je teško posložiti u usporednu analizu u kojoj bi se utvrdila motivska ovisnost. Proučavajući zastupljenost, funkciju i simboliku botanike ove bajke mogu se uočiti kategorije koje pripadaju tradicijskim vjerovanjima pretkršćanskog karaktera, kao i specifični simbolički obrazac koji postoji u biblijskom vjerovanju o stablu spoznaje dobra i zla. Sve to upućuje na simboličke vrijednosti pretkršćanskog i kršćanskog karaktera, iako ovaj kršćanski karakter korijenje ima u pojedinim motivima kršćanske mitologije.

\footnotetext{
${ }^{9}$ Usp. Suzana MARJANIĆ, Imaginarij mitske botanike u Pričama iz davnine, Republika, 55 (1999) 7-8, 196-212, 196.

${ }^{10}$ Usp. Celestin TOMIĆ, Simbolika stabla, Obnovljeni život - časopis za filozofiju i religijske znanosti, 42 (1987) 5, 428-432, 430; Anđelko BADURINA (ur.), Leksikon ikonografije liturgike $i$ simbolike zapadnog kršćanstva, 4. dop. izd., Zagreb, Kršćanska sadašnjost, 2000, 320.
} 


\section{Ribar Palunko i njegova žena}

Ova bajka nema mnogo spomenutog bilja koje bi se moglo proučavati, no zato u svom drugom dijelu spominje vinovu lozu, mandulu i plod zlatnu jabuku. Na samom početku spominje se loboda (Atriplex hortensis) kao osnovna sirotinjska ribarska hrana i taj dio pripada etnokulturalnoj kategoriji prehrambenih navika čovjeka koji živi pored mora. No, kako bajka ide dalje tako se javljaju specifični botanički motivi koji imaju svoju simboličku vrijednost. Primjerice, kada Palunko s čunom dođe do otoka Bujana, prebivališta Zore-djevojke i mjesta koje upućuje na njegovo rajsko značenje, budući da na njemu raste svakojakog obilnog raslinja kojeg nema na obalama gdje Palunko živi, tako na tom otoku vidi vinovu lozu i rascvjetane mandule (badem) iz kojih je razvidno da su to simboli bogatstva, obilja i u konačnici plodnosti. Badem simbolizira tajnu u sjeni koju tek treba otkriti, simbolizira visoku i skrivenu duhovnost, jezgru onog najvrjednijeg. ${ }^{11}$

Međutim, najznačajnije mjesto u bajci zauzima plod zlatne jabuke koja se više puta spominje i koja ovdje simbolizira bogatstvo bez granica, ali i predmet obožavanja koji nadilazi vrijednost zlata. Tako je Palunkovo dijete atribuirano zlatnom jabukom. Kontekstom mita godišnje rodnosti ${ }^{12}$ i simbola obilja u ovoj bajci je zlatna jabuka predmet iznimne vrijednosti. Osim toga, zlatna jabuka je u bajci dana u ruke Palunkovu djetetu Vlatku te je na taj način simbolika obilja, plodnosti u obliku djeteta i najveće vrijednosti spojen u dvodijelni simbol djeteta sa zlatnom jabukom. No u trenutku kada dijete ide zagrliti majku, ispada mu zlatna jabuka te se njen gubitak ne tumači kao nesreća već se suptilno ističe vrijednost ljubavi nad zlatom i obiljem. Osim toga u doba antičkog Rima je zlatna jabuka u ruci vladara označavala zemaljsku kuglu - orbis terrae, a to znači carsku suverenu moć nad zemljom. ${ }^{13}$ Ta logika, najvećeg obilja i blagostanja koje čovjek blagom može zadobiti vidi se u bajci Bratac Jaglenac i sestrica Rutvica gdje se oholi ljudi igraju zlatnim jabukama kao loptama ili bućama te na taj način uništavaju sve što je pošteno stečeno. ${ }^{14}$ Zanimljivo je da se mediteranski mitski kontekst prepliće s pojedinim motivima slavenskih bajkovitih svjetova (morski kralj i morske djevice) na osnovu kojih autorica gradi vlastiti artistički svijet. ${ }^{15}$ Preuzimanje motiva morskih djevica iz Valjavčeve zbirke ili morskog kralja iz Afanasjevih zapisa govore o inspiraciji koju je književnica crpila iz raznih izvora. Tom selekcijom motiva može se proučavati i motiv zlatne jabuke u ovoj bajci, što u konačnici upućuje na zaključak da je književnica koristila i slavenske i mediteranske motive da bi umjetnički izgradila svijet i likove u bajci.

\footnotetext{
${ }^{11}$ Usp. Visković, nav. dj., 380.

${ }^{12}$ Usp. Radoslav KATIČIĆ, Zlatna jabuka, Filologija, 52 (2009) 1-86, 1.

${ }^{13}$ Usp. Visković, nav. dj., 395.

${ }^{14}$ Usp. Brešić, nav. dj., 145.

${ }^{15}$ Usp. Andrijana KOS-LAJTMAN, Jasna HORVAT, Ivana Brlić-Mažuranić. Priče iz davnine, nova konstrukcija izvora i metodologije, Fluminensia, 23 (2011) 1, 87-99, 92.
} 


\section{Regoč}

Slično kao i u bajci Ribar Palunko i njegova žena, ovdje se spominje vrt koji je bogat svakojakim biljem i simbol je plodnosti i života te u tom vrtu cvatu naranče i dafine (ruske grmolike masline, zlolesine). Vidljiv je orijentalni motiv bogatstva vrta jer se izrijekom spominju naranče, koje su za neke proučavatelje mitologije upravo zlatne jabuke iz grčke mitologije, ${ }^{16}$ te se spominju ruske masline koje rastu u zapadnoj i središnjoj Aziji od južne Rusije i Kazahstana do Irana, Turske, Afganistana. ${ }^{17}$ Slijedom proučavanja motiva o zlatnim jabukama, biljkama i stablima i u ovoj se bajci mogu uočiti motivski obrasci koji se mogu dovesti u vezu s mediteranskim i slavenskim kulturnim prostorom.

Predodžba o savršenom vrtu ovdje počiva u kolekciji divnih botaničkih primjeraka koji dolaze iz dalekih krajeva kao posebne visoko cijenjene biljne vrste, što može evocirati na davno napušteni savršeni svijet koji je prema kršćanskoj tradiciji postojao u Edenskom vrtu kao simbolu savršenog sklada čovjeka i prirode. Stoga ne čudi da se slijedom kršćanskog mita o deterioraciji svijeta kroz vrijeme ovdje pokušava svijet ponovno vratiti u prvotno »čisto« stanje nakon kataklizme potopa, što ponovno asocira na starozavjetnu priču o općem potopu i obnovi svijeta i čovjekova saveza s Bogom.

\section{4. Šma Striborova}

Budući da je jedan od motiva ove bajke upravo začarana šuma, možemo očekivati da se biljni motivi rasprostiru po cijelom tekstu, no nije tako. U ovoj bajci spominju se tri biljke, stabla, i to: kesten u žeravici, glogov grm i divovski dub, hrast. Kesten je spomenut kao izvor pucketanja i raspršivanja pepela da bi se skrilo Malika Tintilinića, no nije zapravo prisutan u bajci. Baka koristi ovu obmanu da bi navela nevjestu da ne nastavi pretraživati ognjište. Kesten u narodnoj tradiciji ima razmjerno slaba simbolička značenja. ${ }^{18}$ Ozbiljnije simboličke vrijednosti prepoznaju se kod prizora u kojem se Malik popne na glogov grm. ${ }^{19}$ $\mathrm{Tu}$ je baka u potrazi za Striborom kako bi se riješila zle duše uobličene u guju pa u djevojku nevjestu, a Malik Tintilinić se penje na grm gloga pa zviždukom dozove jelena i dvanaest vjeverica. Jelen je u mnogim mitologijama povezan sa svojim prirodnim staništem koje poprima mitsku dimenziju postavši tako mitski jelen u mitskoj šumi. Počevši od četiriju jelena koji se hrane sa stabla

\footnotetext{
${ }^{16}$ Usp. Orange (Citrus sinensis [L.] Osbeck), Gernot Katzer's Spice Pages, (03.02.1999) http:// gernot-katzers-spice-pages.com/engl/Citr_sin.html\#etym (08.02.2018).

${ }^{17}$ Usp. Ruska maslina (Elaeagnus angustifolia), Priroda i biljke, http://www.plantea.com.hr/ ruska-maslina/ (08.02.2018).

${ }^{18}$ Usp. Visković, nav. dj., 392.

${ }^{19}$ Usp. Brešić, nav. dj., 117.
} 
Yggdrasila, ${ }^{20}$ preko kulta jelena u keltskim tradicijama ${ }^{21}$ do atribucije Artemide i Dijane $u$ antičkim mitologijama.

Osim toga, pri izradi šamanskog bubnja sibirskih stanovnika koristi se jelenova koža i okvir od drveta, a za oba predmeta postoji mitološka poveznica koja ih objedinjuje u predmet visokog religijskog, duhovnog i mitološkog značaja. Sibirski narodi spajaju vjerovanje u moć kože praoca svih jelena i okvira od drveta koji je izrađen od drva života te se na taj način jelen i drvo ponovno spajaju u novoj mitskoj kategoriji komunikacije s dušama predaka. ${ }^{22}$ Sukladno dosadašnjim mitskim motivskim osnovama i ovdje jelen obitava u začaranoj šumi i ima pozitivne atribute. $U$ tom smislu Malikov zvižduk zova s gloga itekako ima simboličko značenje budući da se na taj način Malik jelenu identificirao kao biće koje nije demon niti je u službi zla. U protivnom bi bježao od gloga za kojeg predajna tradicija i vjerovanje tumače da je isključivo apotropejskog karaktera te da tjera demone, duhove, vampire i druga bića koja su bila atribuirana negativnim djelovanjem na čovjeka. ${ }^{23}$ Glog se kod južnih Slavena naziva i svetim drvetom upravo zbog svoje apotropejske moći ${ }^{24}$ pa taj prizor ima još snažnije značenje. ${ }^{25}$ Mitološka podloga za razumijevanje uloge jelena kao sluge kralja začarane šume postoji i u opisu centra same magijske vlasti šume Striborove u kojoj se nalazi dub, hrast koji je ujedno i okvir Striborove moći. ${ }^{26}$ To je nadnaravno velik dub, hrast: »Stribor pak bijaše šumski starješina. Sjedio je sred šume, u dubu tako velikom da je u njem bilo sedam zlatnih dvorova i osmo selo, srebrnom ogradicom ograđeno. ${ }^{27}$ Po sredini šume nalazi se najveće i najsvetije stablo koje je ujedno i tron Striboru. Takav šumski kralj može predstavljati božanstvo ili pak duha šume koji njome vlada i iz nje proizlazi.

Živa osoba za koju se vjeruje da u sebi utjelovljuje duh drveća naziva se u raznim europskim kulturama kraljem i poznato je da u tim kulturama duh može biti i samo stablo. ${ }^{28} \mathrm{U}$ ovom slučaju Stribor je živo biće koje utjelovljuje moć nad svojim kraljevstvom i zajedno s propašću kraljevstva propada i on. On je svojevrstan starješina šume koja njemu pripada (šuma Striborova). ${ }^{29}$ Svetost hrasta zabilježena je kod Baltičkih Slavena u 12. stoljeću kada je u baltičkom

\footnotetext{
${ }^{20}$ Usp. Snorri STURLUSSON, Edda - Gylfaginning/Obmanjivanje Gylfija, prev. Dora Maček, Zagreb, ArTresor naklada, 1997, 59.

${ }^{21}$ Usp. John George McKAY, The Deer-Cult and the Deer-Goddess Cult of the Ancient Caledonians, Folklore 43 (1932) 2, 144-174, 174.

${ }^{22}$ Usp. Esther JACOBSON, The Deer Goddess of Ancient Siberia. A Study in the Ecology of Belief, New York - Köln, E. J. Brill, Leiden, 1993, 176.

${ }^{23}$ Usp. Visković, nav. dj., 391.

${ }^{24}$ Usp. Vinšćak, nav. dj., 125.

${ }^{25}$ Usp. Marjanić, nav. dj., 203.

${ }^{26}$ Više o toj temi vidi u: McKay, nav. $d j$.

${ }^{27}$ Brešić, nav. dj., 118.

${ }^{28}$ Usp. James G. FRAZER, Zlatna grana. Podrijetlo religijskih obreda i običaja, prev. Dinko Telećan, Zagreb, Naklada Jesenski i Turk i dr., 2002, 87.

${ }^{29}$ Usp. Biljana VIDIČEK, O imenima u Pričama iz davnine Ivane Brlić-Mažuranić (Stribor, Regoč), u: Majhut, Narančić Kovač, Lovrić Kralj (ur.), nav. dj., 681-696, 685.
} 
pomorju postojao veliki hrast za kojeg je puk vjerovao da je sveto stablo jer $\mathrm{u}$ njemu stanuje božanstvo. ${ }^{30} \mathrm{O}$ mitološkom značenju hrasta u slavenskoj kulturnoj tradiciji i vjerovanju pisalo je nekoliko hrvatskih autora, među kojima su najznačajniji Radoslav Katičić, ${ }^{31}$ Vitomir Belaj, ${ }^{32}$ Tomo Vinšćak ${ }^{33}$ i Petar Bulat. ${ }^{34}$ Uz hrvatske znanstvenike koji su pisali o hrastu kao svetom drvu Slavena, niz vjerovanja koja su rasprostranjena po svim slavenskim zemljama te se u tom kontekstu hrast često povezuje i s drvom svijeta ${ }^{35}$ kod Slavena. ${ }^{36}$ Kod većine Indoeuropljana hrast zauzima središnje mjesto u vjerovanjima o stablima, štovan je kao sveto drvo $u$ mnogih indoeuropskih naroda ${ }^{37} \mathrm{i}$ nije čudo što je $u$ ovoj bajci upravo dub, hrast centar vladarske moći šumskog vladara. Također, vjerovanje da munja najčešće udara $u$ hrast potječe iz germanskih vjerovanja gdje Donar upravlja munjama i sam ih baca. ${ }^{38}$

Osim toga, pravda se nekada izricala pod hrastovima u vjeri da je zakon time dobio i svetu vrijednost. ${ }^{39}$ Primjerice, 1990-ih godina u dolini Neretve se pripovijedalo da se nekada u Širokom Brijegu, a i drugdje u Hercegovini, ispod hrasta krstilo djecu i vjenčavalo mladence u vremenima kada je crkva bila zatvorena zbog ideoloških razloga nekadašnje Jugoslavije. ${ }^{40}$ Znalo se diskreditirati sakrament krštenja kod pojedinih osoba govoreći: »Pusti njega, njega su ti poda dubom krstili.« Brojni su dokazi koji idu u prilog tezi da je hrast kao središte začarane šume Striborove drvo koje ima svoju vrijednost u kategoriji mitološke svetosti te se kao takav opisuje u ovoj bajci. Od svih stabala koja su spomenuta u pričama iz davnine, ovo je najveće stablo i Ivana Brlić-Mažuranić ga je očito s razlogom tako prikazala upravo tradicijskim vjerovanjem o dubu, hrastu. Tezu da je Striborova šuma vjerojatno borova šuma iznijela je Biljana Vidiček analizirajući ime Stribor i pridajući dvostruko značenje dubu promatrajući ga ne samo kao hrast nego i kao bilo koje drugo drevno stablo, otvarajući mogućnost promatranja šume Striborove kao šume borova. ${ }^{41}$

\footnotetext{
${ }^{30}$ Usp. Radoslav KATIČIĆ, Božanski boj, Zagreb - Mošćenička Draga, Ibis grafika, 2008, 55.

${ }^{31}$ Radoslav KATIČIĆ, Čudesno drvo, Filologija, 45 (2005) 47-86.

${ }^{32}$ Vitomir BELAJ, Hod kroz godinu. Pokušaj rekonstrukcije prahrvatskoga mitskoga svjetonazora, 2. izmijenjeno i dopunjeno izdanje, Zagreb, Golden marketing - Tehnička knjiga, 2007.

${ }^{33}$ Vinšćak, nav. dj.

${ }^{34}$ Petar BULAT, Pogled u slovensku botaničku mitologiju, Narodna starina, 11 (1932) 27, 1-26.

${ }^{35}$ Usp. Vinšćak, nav. dj., 48.

${ }^{36}$ Usp. Bulat, nav. dj., 2-5.

${ }^{37}$ Usp. Vinšćak, nav. dj., 52.

${ }^{38}$ Usp. Jacob GRIMM, Teutonic Mythology, sv. 1, London, George Bell and sons, 1882, 172.

${ }^{39}$ Usp. Visković, nav. dj., 370.

${ }^{40}$ Kazivali anonimni govornici iz doline Neretve u razgovoru s Denisom Vekićom 1997. godine.

${ }^{41}$ Usp. Vidiček, nav. dj., 686.
} 


\section{Bratac Jaglenac i sestrica Rutvica}

Zanimljivo da autorica, kada gradi botaničku vizuru svijeta u kojem se junaci nalaze, u ovoj bajci navodi postojanje nižeg raslinja. Kada opisuje idiličan otok Avalon ili Bujan autorica koristi tradicionalan opis mjesta izdvojenog iz svijeta na Kitež-planini, mjesta koje je blaženo u postojanju i brazdom odvojeno od svih nedaća, na tom je mjestu, oko jezerca, cvalo i mirisalo cvijeće. ${ }^{42}$ Već brazda čini granicu dvaju svjetova te se očekuje da će s onu stranu granice biti neki visoko fantastičan svijet. Međutim, iza te brazde jezerce je ispunjeno šašom, vodenom travom i rogozom - biljem tipičnim za plitke vodene površine koje graniče s močvarnim ambijentom. To bilje služi Rutvici kao most do otoka u sredini jezerca te ima svoju utilitarnu svrhu kojoj je simbolična vrijednost smanjena i svedena na oslonac pod nogama, iako se donekle to isto bilje može promatrati i kao simboličan most prijelaza do tajnovitog i mitski značajnog mjesta, kao što je jezerce na Kitež-planini.

U daljnjem tekstu bajke značajnu ulogu imaju maline i otrovne jagodice. Maline su ovdje predstavljene kao hrana djeci. Maline su se, u mitološkom smislu, dovodile u odnos prema plodnosti, a u grčkoj mitologiji čine poveznicu s djecom u priči o Idi, Zeusovoj dadilji koja se ubola u prst dok je brala maline te ih tako zauvijek ocrvenila. ${ }^{43}$ Upravo je u ovoj bajci riječ o crvenim malinama. ${ }^{44}$ Simboličke vrijednosti malina povezane su s nevinošću djece, što nije zanemarivo jer se maline, a posebno crvene, dovode u nekoliko simboličkih i folklorističkih poveznica s trudnoćom, porodom i djecom. ${ }^{45}$ Propavši u rupu sa zašiljenim kolcima i bodljama Jaglenac je, onako lak, ostao ležati na lišću koje se nakupilo ispod njega, a autorica koristi izraz »kao da na bosiljku spava « ${ }^{46}$ implicirajući na blagotvorno djelovanje bosiljka na čovjeka.

Crvene i crne jagode su opisane kao otrovni plodovi koji ubijaju svakog tko ih pojede, osim ako se ne pojedu i crvene i crne jagode, kao što je Jaglenac učinio, te stoga autorica piše: »Crveni otrov ubio u Jaglencu crni otrov. « ${ }^{47}$ Najbliža asocijacija poziva na oprez pri branju jagoda u ovoj bajci može biti dio teksta $u$ djelu Roman de la rose gdje se upozorava djecu da ne beru jagode jer ih zmija ispod lišća može ujesti. ${ }^{48}$

${ }^{42}$ Usp. Brešić, nav. dj., 125.

${ }^{43}$ Usp. Barbara M. SCHMIDT, Diana M. KLASER CHENG (ur.), Ethnobotany. A Phytochemical Perspective, Hoboken, John Wiley \& Sons, 2017, 54.

${ }^{44}$ Usp. Candace HUNTER, Raspberry. History, Folklore, Myth, and Magic, (17.10.2008) http:// www.thepracticalherbalist.com/holistic-medicine-library/raspberry-myth-and-magic/ (08.02.2018).

${ }^{45}$ Usp. Alexander COURTNEY, Berries as symbols and in folklore, New York Berry News, 6 (2007) $1,1-4,3$.

${ }^{46}$ Usp. Brešić, nav. dj., 128.

${ }^{47}$ Isto, 135.

${ }^{48}$ Usp. Monica BOWEN, Strawberries as an »Earthly Delight«, (09.07.2011) http://albertiswindow.com/2011/07/strawberries-as-an-earthly-delight/ (07.02.2018). 
Et notés ces vers de Virgile,

Mes qu'en vos cuers si les fichiés,

Qu'il n'en puissent estre sachiés:

Eufans qui coilliés les floretes,

Et les fréses fresches et netes,

Ci gist li frois serpens en l'erbe;

Fuiés, enfans, car il enherbe

Et empoisone et envenime

Tout home qui de li s'aprime. ${ }^{49}$

Jagode se obično povezuju s pozitivnim simbolima te predstavljaju ili djevičanstvo ili savršenu pravednost, ${ }^{50}$ što se može povezati s malenim Jaglencom, ali samo u kontekstu njegove nevinosti pred napadom vila zatočnica i u pravičnom susretu s pokušajem trovanja jagodama. Zlatne jabuke opisuju se i u ovoj bajci, kao što je već prethodno spomenuto na početku rada. Slijedeći atribuciju zlatnih jabuka kao simbola obilja, plodnosti i najvećeg bogatstva, vladari u kneginjinu dvoru rasipaju bogatstvo te se tako »meću zlatnim jabukama preko saga svilom izvezenih.$^{51}$ Osim toga, iz ruske svadbene pjesme i jedne hrvatske pjesme poznato je da kotrljanje zlatnih jabuka dovodi do njihova raspadanja i da može imati razorne posljedice za okolinu..$^{52}$ Pri opisu susreta Relje i djevojčice Rutvice koristi se opis »djevojčica, kao ružica bijela « ${ }^{53}$ kojim se implicira značenje bijele ruže u kontekstu djevojačke čistoće. Ovo je važna atribucija stoga što se junak Relja poslije oženi djevojkom Rutvicom. Suzana Marjanić iznosi tezu o botaničkim vrijednostima imena Jaglenca i Rutvice, gdje Jaglenac posredstvom cvijeta Jaglaca poprima značenje solarnoga kulta, a Rutvica posredstvom biljke rute poprima apotropejsko značenje..$^{54}$

Prilikom prvog ulaska glavnih likova bajke u nove, bijele dvore opisuje se veliko slavlje pri kojem su seoska dječica »sterala neven i bosiljak, kuda oni stupahu«. ${ }^{55}$ Čašćenje gospodara ovim biljem značajno je radi ljekovitih svojstava i pozitivnih atribucija nevena i bosiljka. U tom smislu, novi stari gospodari dvora su blagoslovljeni od samog naroda te im se na taj način osigurava dug i zdrav život. Neven se koristi za liječenje mnogih bolesti i sveprisutan je u vjerovanjima i magijskim spravljanjima lijekova. Bosiljak je također prisutan u etnomedicini i za njega se vjeruje da ima visoku medicinsku vrijednost, što se znanstveno i potvrdilo.

\footnotetext{
${ }^{49}$ Guillaume DE LORRIS, Le Roman de la Rose, Paris, Librairie de Firmin Didot frères, fils et Cie, 1864, 190.

${ }^{50}$ Usp. Representing God and the Saints. Plants, trees and flowers, http://www.catholictradition. org/Saints/signs4.htm (07.02.2018).

${ }^{51}$ Brešić, nav. dj., 145.

${ }^{52}$ Usp. Radoslav KATIČIĆ, Zeleni lug. Tragovima svetih pjesama naše pretkršćanske starine, Zagreb, Ibis grafika, 2010, 213-214.

${ }^{53}$ Brešić, nav. dj., 149.

${ }^{54}$ Usp. Marjanić, nav. dj., 203.

${ }^{55}$ Brešić, nav. dj., 157-158.
} 


\section{Lutonjica Toporko i devet župančića}

Budući da ovoj bajki priča počiva na transformaciji drveta u mladića, očekuje se da će se simbolika drveća snažno poticati te da će služiti opisu likova. Zibanjem panjeva devet mladih javorovih stabala rađaju se nadnaravnim putom djeca koja svojom dobrotom i ugledom poprimaju simboličke vrijednosti stabala iz kojih su nastali. ${ }^{56} \mathrm{U}$ ovom motivu prepoznaje se i drevna mitska slika dendromorfnog rođenja gdje se tumači da je čovjek nastao od stabla. ${ }^{57} \mathrm{U}$ narodnoj tradiciji poznato je da se gusle prave od javorova drveta i smatra se da je upravo to drvo najpogodnije za izradu toga glazbala. Isto tako javor se koristi kao tvrdi gradbeni element pokućstva, ali i drugih predmeta. Tako za gradbeni element fantastičnog stvaranja svoga brata, dvije sestre iz usmene narodne pjesme njegove kosti prave od javora:

Dvi sestrice brata ne imale,

Pa ga vile od bijele svile.

Kosti su mu drvo javorovo. ${ }^{58}$

Stoga ne čudi da je upravo motiv iz usmenih narodnih pjesama podloga za odabir javorova drveta za gradbeni element tijela devetero djece. Isto tako javor je drvo kojem se mlade djevojke u pjesmama obraćaju u dijaloškoj formi:

Oj javore, zelen bore,

Lako ti je zeleniti

I zelenu tebi biti!

I ja bi' te mlada brala,

Ali sada nemam kada. ${ }^{59}$

Osim zaziva javor drva ponekad se ono i opisuje:

Oj javore, zelen bore.

Zelen ti se zelenio,

Tanke grane razavio.

Kud ti grane razaprle,

Onud ovce plandovale. ${ }^{60}$

Javor se spominje u pjesmi i kao mjesto radnje jer pored njega izlazi voda:

Izvirala studena vodica

Pod suhijem drvom javorovim;

Tuđe Luče na vodu dolazi,

Sa svojom se smrti razgovara. ${ }^{61}$

\footnotetext{
${ }^{56}$ Usp. isto, 161-163.

${ }^{57}$ Usp. Marjanić, nav. dj., 206.

${ }^{58}$ Nikola ANDRIĆ (ur.), Hrvatske narodne pjesme. Ženske pjesme, knjiga sedma, odio drugi/ sveska treća, Zagreb, Matica hrvatska, 1929, 142.

${ }^{59}$ Isto, 44.

${ }^{60}$ Isto, 117.

${ }^{61}$ Isto, 66.
} 
Još jedan primjer povezuje drvo javora s izviranjem vode:

Izvir-voda izvirala,

Izvrh polja, iz javora,

Po polju se razlivala. ${ }^{62}$

U Novom Vinodolskom početak pjesme također obilježava izviranje vode uz javorovo stablo:

\section{Izvir-voda izvirala}

Iz korita javorova;

U polje se salivala. ${ }^{63}$

Lipa je bila zvana svetim stablom kod slavenskih naroda. U Češkoj zauzima i mjesto nacionalnoga stabla, a u Poljskoj više naselja nosi naziv Święta Lipka u značenju sveta lipa.$^{64}$ Osim toga, lipa je u poljskoj kulturi zauzela i mjesto u kršćanskoj religijskoj praksi gdje su likovi blažene djevice Marije napravljeni od drva lipe, a i sami likovi Majke Božje se mogu pronaći u usječenim nišama stabla lipe. ${ }^{65}$ Osim prepoznavanja lipe kao svetog stabla, poznate su tradicije davanja bračnih zavjeta ispod lipe kod germanskih i slavenskih naroda. ${ }^{66}$ Sudski događaji su se također odvijali ${ }^{67} \mathrm{u}$ ruralnim dijelovima Njemačke. ${ }^{68} \mathrm{U}$ ovoj bajci Brlić-Mažuranić koristi taj drevni motiv sudišta ispod lipe u posljednjim prizorima gdje župan Jurina u ulozi vladara i sudca sjedi ispod lipe:

"Sjedi župan Jurina pod lipom, na stolici srebrom okovanoj, a stolica podignuta na dvije stepenice; stepenice baršunom obložene. (...) Pred županom na deset koraka poredala se sva čeljad i dvorjani - a sve mukom muči s počitanja. « ${ }^{69}$

Iz svega navedenog, stablo lipe je u ovoj bajci korišteno u ulozi svetog stabla pod kojim se obavlja suđenje, ispunjavajući tradicijsko vjerovanje o lipi kao mjestu okupljanja i sudbene pravde. U zadnjem dijelu bajke lipa i prostor oko lipe preuzimaju ulogu pozornice i mjesta radnje te joj se funkcija uzdiže u vrjednije simbole ove bajke.

\footnotetext{
${ }^{62}$ Isto, 173.

${ }^{63}$ Isto, 255.

${ }^{64}$ Usp. Alina Maria TENCHE-CONSTATINESCU i dr., The symbolism of the linden tree, Journal of Horticulture, Forestry and Biotechnology, 19 (2015) 2, 237-242, 239.

${ }^{65}$ Usp. Magdalena WÓJTOWICZ, Etnografia Lubelszczyzny, http://teatrnn.pl/leksykon/ artykuly/ etnografia-lubelszczyzny-ludowe-wierzenia-o-drzewach/\#charakterystykawybranych-drzew-lipa (17.02.2018).

${ }^{66}$ Usp. Lamus DVORSKI, Linden Tree. Trees in the Polish (Slavic) folklore and culture. Part 1, s polj. na engl. prev. Willian Auld, (19.03.2017); https://lamusdworski.wordpress.com/2017/03/19/ linden-tree/ (12.02.2018).

${ }^{67}$ Više o tome vidi u: Doris LAUDERT, Mythos Baum. Was Bäume uns Menschen bedeuten. Geschichte, Brauchtum, 30 Baumporträts, München, BLV Verlagsgesellschaft, 2003.

${ }^{68}$ Usp. Christhard EHRIG, Kulturgeschichte des Baumes. Vom Kultbaum zum Straßenbegleitgrün, predavanje održano u lipnju 2005. u Münsteru, Landschaftsverband Westfalen-Lippe, 1-30, 10; http://www.lwl.org/walb-download/pdf/ehrig_screen.pdf (11.02.2018).

${ }^{69}$ Brešić, nav. dj., 188.
} 


\section{Sunce djever i Neva Nevičica}

Iako se u ovoj bajci drveća ne spominju toliko kao što je to slučaj s prethodnom, značajno je spominjanje badnjaka i hrastove gradine Oleha bana. Badnjak je u hrvatskoj tradiciji gotovo bez iznimke hrast te se u ovdje spominje u kontekstu godišnjeg razdoblja za koje se vjeruje da je sunce ranjivo, malo i gladno. To je jako bitno za fabulu ove bajke jer se upravo na hranjenju mladoga sunca temelji sunčeva pomoć Nevi Nevičici i Olehu banu na kraju fabule. Cijela fabula evolvira oko rasta maloga sunca te se tako i hrastova gradina, kao mjesto gdje ban prebiva, uklapa u kozmički odnos sunca i hrasta.

Već spomenuta vjerovanja za stablo hrasta ovdje se podrazumijevaju jer se hrastova gradina postavlja kao topos suprotstavljanja zlu i u konačnici Mokoš, koja se u religijskim atribucijama nalazi nasuprot Perunu koji živi na gori i kojem su atributi hrast ${ }^{70}$ i $_{\text {orao. }}{ }^{71}$ Atribut svetosti hrastove gradine vidljiv je $u$ tome što njegovim stanovnicima ne pomaže Mokoš nego sunce koje predstavlja božansku snagu na svijetu. U ovoj bajci još se javlja biljka štir u kojoj se nalaze ključevi koje je kraljevna izgubila, no simboličke vrijednosti štira nisu toliko poznate kao što je to slučaj kod drugih biljaka i stoga što je on u Europu iz Južne Amerike došao relativno kasno u odnosu na druge vrste biljaka koje su dovoljno dugo bile prisutne na prostoru Europe da se kroz povijest čovječanstva uz njih razviju višeslojne simboličke i značenjske funkcije.

\section{Jagor}

Početak ove bajke obilježen je tipičnim agrarnim motivima koji su vezani uz vjerovanja u žitne duhove i žetelačku tradiciju. Nalazi se lik Bagana koji se namjestio u pleter pšenice te tako čuva blago od svih nesreća. Bagan ima funkciju slavenskog домово́й koji čuva domaćinstva i rogato blago. ${ }^{72}$ Budući da živi u pleteru pšenice u staji Bagan se može u ovom kontekstu povezati i s čuvarom polja budući da je pšenica najčešći simbol plodnosti i blagostanja, a s druge strane može ga se promatrati i kao biće koje je povezano $s$ kultom vegetacije. Također, u bajci se spominje polje raži koje ovdje ima funkciju tipičnog agrarnog prostora u kojem se uzgaja raž i nema neko dublje simboličko značenje, dok hrastov stolac pomaže Jagoru u obliku antropomorfiziranog predmeta.

Smreka i borovica u bajci pak predstavljaju loš izvor hrane kojom bi se mogle životinje nahraniti. Značenje smreke i borovice u ovom slučaju poprima negativan karakter i predstavlja škrtost uvjeta za život. Pri opisu djelovanja babe Poludnice koja napastuje i krade djecu spominje se kopriva koju ona nosi

\footnotetext{
${ }^{70}$ Usp. Grimm, nav. dj., 171.

${ }^{71}$ Usp. Katičić, Božanski boj..., 111.

${ }^{72}$ Usp. Brešić, nav. dj., 213-214.
} 
u snopu i njome ošine malog Jagora. ${ }^{73}$ Iako je u etnobotanici poznata ljekovitost koprive, te u mitologiji povezanost koprive s Donarom, germanskim bogom gromova, ${ }^{74} \mathrm{u}$ ovom slučaju kopriva babi Poludnici služi kao oružje omamljivanja i štete te evocira neugodno djelovanje koprive na kožu.

\section{Zaključak}

Širok je spektar motiva stabala i biljki koje Ivana Brlić-Mažuranić koristi u Pričama iz davnine. Tako je vidljivo da su jasno određene funkcije hrasta i lipe kao važnih stabala u vladarskoj i sudbenoj kategoriji te njihovo uklapanje u dosadašnja vjerovanja o drveću kod Slavena i posebice Hrvata. Autorica posebnu pozornost u bajkama pridaje hrastu, lipi i bukvi. S obzirom da je hrast općepoznato sveto stablo kod Slavena i Germana kao i kod Indoeuropljana uopće, ne čudi što ga autorica upotrebljava kao mitološko stablo u bajci Šuma Striborova. Posebno je uočljiva funkcija duha prirode uobličenog u Stribora koji u bajci nema svoj vizualni opis te takav pristup autorice otvara prostor za tumačenje Stribora kao duha stabla i vladara šume gotovo u božanskoj funkciji. Hrast u kojem boravi Stribor svakako je ujedno i centar kraljevstva i samo kraljevstvo te gotovo preuzima funkciju stabla svijeta. Lipa zauzima posebno mjesto u bajci Lutonjica Toporko i devet župančića posebno zbog toga što predstavlja tradicijsko stablo pod kojim su se u davnini održavala seoska okupljanja, izricale svadbene zakletve i sudbena okupljanja te se i u ovoj bajci lipi pridaju jednaka motivska značenja i jednake osobine. U tom motivu se očituje mješavina tradicijske sudbene prakse germanskih i slavenskih naroda. Tradicija sudbene prakse pod lipom je toliko raširena u europskom prostoru da se još spori o tome je li taj običaj germanskog ili slavenskog podrijetla. Lipa je u slavenskoj tradiciji zauzimala mjesto svetog stabla koje je često sađeno u sredini sela, kao što je slučaj kod Slovenaca i drugih slavenskih naroda.

Motiv zlatne jabuke koristi se u skladu s njenim značenjima kroz mitologiju i vjerovanja o plodu ove voćke. Zlatne jabuke se opisuju u dvije bajke i imaju slične motivske vrijednosti. Uočava se disonantni odnos mitološkog i etnobotaničkog među pojedinim bajkama ovog djela, ali i unutar samih bajki, tako da se primjerice u Ribaru Palunku javlja loboda kao sirotinjska hrana i zlatna jabuka kao voće mitološke simboličke razine prisutno u više različitih mitologija.

Nisko raslinje se spominje u Pričama iz davnine i to najčešće kao ljekovito bilje kojim se implicira njegovo blagotvorno djelovanje na odnose među likovima. Iako je poznavanje niskog raslinja često manje izraženo u odnosu na poznavanje svetosti stabala, u Pričama iz davnine ono ima važno mjesto,

\footnotetext{
${ }^{73}$ Usp. isto, 215.

${ }^{74}$ Usp. Ivo PAUWELS, Gerty CHRISTOFFELS, Herbs - Healthy living with herbs from your garden, Cape Town, Struik Publishers, 2006, 37.
} 
posebno u slučaju bajke Bratac Jaglenac $i$ sestrica Rutvica gdje maline i jagode preuzimaju simboličke vrijednosti kakve su imale u antičkom i srednjoeuropskom tradicijskom vjerovanju.

Mitološki kontekst je sveprisutan u Pričama iz davnine, no autorica se vodi vlastitom kreativnom ingenioznošću pri stvaranju radnje, odnosom i funkcijom likova. Isto tako, koristi se svojevrsnim univerzalnim vrijednostima tradicijskih vjerovanja botaničkog karaktera. Autorica koristi pojedine simboličke vrijednosti flore, no jednako im pridaje i nova značenja koja su u skladu s postavljenim svijetom vjerovanja i nadnaravnog u Pričama iz davnine. Mitološke obrasce prilagođava bajkama, mitska botanika adaptirana je tradicijskim vjerovanjima, no nemaju svugdje tako istaknutu funkciju. Dosadašnjim istraživanjima o izvornosti bajki iz Priča iz davnine utvrdilo se da književnica uistinu crpi ideje za pojedine likove iz usmene književnosti, a posebice iz sklopa vjerovanja i tradicijskih bajki slavenskoga kulturnog kruga. Slično se događa is botaničkim motivima u Pričama iz davnine gdje se uočavaju mitski obrasci i vjerovanja pri korištenju pojedinih stabala i biljaka u bajkama. Za razliku od likova za koje se može reći da su produkt književničine ingenioznosti, pojava stabala i biljaka u Pričama iz davnine u skladu je s općim tradicijskim vjerovanjima i predodžbama koje su baštinili, u najširem kulturnom smislu, Indoeuropljani te se tragovi tih vjerovanja mogu potvrditi i u suvremenoj usmenoknjiževnoj istraživačkoj praksi. Osim mitske kategorije koja postoji u percepciji hrasta ili duba u bajci Šuma Striborova, opisuje se još i zlatna jabuka kao motiv iz mitske priče čiji se korijen može tražiti i u antičkom mitu o Atlanti i zlatnim jabukama. S druge strane, niz tradicijskih vjerovanja koji se odnose na lipu, hrast i ljekovito bilje prenesen je u Priče iz davnine iz stvarnog svijeta. Tu se može vidjeti kako se prepliću botaničke percepcije svojstvene mitskim pričama i pučkom vjerovanju koje je u nekim dijelovima proizašlo iz mitskih percepcija svijeta. Također, kroz Priče iz davnine protežu se obrasci tradicijskog vjerovanja koji se mogu okarakterizirati kao etno-agrarni te se njihova funkcija uočava kroz vizualizaciju romantičarske predodžbe o prirodi i čovjekovu odnosu prema prirodi. Književnica radnju bajki najčešće smješta na otvorene prostore i u blizak kontakt s prirodom, što je karakteristično i za narodne bajke budući da su gotovo sve nastale u društvu koje je živjelo posred prirode u predindustrijskom vremenu. $\mathrm{Na}$ taj način, odabir stabala i biljaka koje su zastupljene u Pričama iz davnine odgovara »domaćoj« percepciji sekundarnog svijeta kojeg književnica stvara. Koristeći imena slavenske mitologije, pridajući likovima sa slavenskim mitološkim temeljem nove vrijednosti i funkcije, književnica gradi bajkoviti svijet slavenskih korijena te je i simbolička vrijednost flore Priča iz davnine u skladu s percepcijom svijeta pretkršćanske slavenske tradicije pa se tako ostvaruje logičnost u povezivanju funkcija likova i simboličkih vrijednosti svijeta i prirode u kojoj se nalaze. 
Možemo dodati da je književnica s odabirom etnobotaničkih vrijednosti postupala u skladu s izvorima na koje se oslanjala pri inspiriranju za pisanje Priča iz davnine. To je vidljivo u nepromjenjivosti simbolike i funkcije flore koja postoji u tradicijskim vjerovanjima slavenskih naroda. Naravno, neka vjerovanja o stablima variraju u značenju i učestalosti od naroda do naroda pa se može uočiti da je simbolika lipe u bajci Lutonjica Toporko i devet župančića zastupljena u vrlo važnim dijelovima bajke, a istraživači poput Bogoslava Šuleka i Vitomira Belaja ukazali su na manjak dokaza koji bi potkrijepili tvrdnju da je lipa bila štovana kod Slavena te ona postaje simbol sveslavenstva. ${ }^{75}$ Međutim zanimljivo je bilo ukazati na važnost štovanja lipe kod Nijemaca, što je bilo prikazano u nekoliko pojedinosti o tradicijskim vjerovanjima vezanih uz lipu.

Ovim radom se pružaju tumačenja značenja pojedinih motivskih vrijednosti stabala i biljaka koja se opisuju u ovom djelu pomoću kojih se pokušalo proučiti simboličke i značenjske smjernice za dublje simboličko razumijevanje Priča $i z$ davnina, posebice u kontekstu drevnih slavenskih vjerovanja, ali i vjerovanja drugih naroda koji su s njima bili u doticaju. Stoga je potrebno promatrati botaničku simboliku u Pričama iz davnine na temelju tradicijskih vjerovanja o stablu i svijetu u baštini Indoeuropljana, a koja se u kontekstu slavenske kulture i hrvatskog naroda sačuvala u obrascima etnokulturalnog vjerovanja o drveću i nekim biljkama.

\footnotetext{
${ }^{75}$ Usp. Marjanić, nav. dj., 197-198.
} 


\section{Vanda Babić" - Denis Vekić"** \\ Symbolic and Meaning functions of flora in Tales of Long Ago by Ivana Brlić-Mažuranić \\ Summary}

Texts with the elements of mythic language are often those in which symbolic values are found and the transcribed and hidden meanings in everything which seems quite commonly and daily. The motives in artistic and folk fairy tales are often attributed with means of one dimensionality, but in the selective use of these motifs there are hidden values and significance which can be interpreted through detailed research and understanding the meaning context of fairy tales. This paper is based on the idea that the author of the Story of Long Ago in her fairy tales used motifs and meanings spectrum which is applied to the flora of Slavic mythology. The use of specific specimens of flora carries symbolic and meaningful functions within which that can be detected by studying the corpus of mythical motifs and elements that were inherited in Slavic mythology and ethnobotanics.

Key words: flora, symbols, Tales of Long Ago, motifs, analysis.

(na engl. prev. Denis Vekić)

\footnotetext{
* Vanda Babić, PhD, Full Prof., Department of Croatian and Slavic Studies at the University of Zadar; Address: Obala kralja Petra Krešimira IV., br. 2, HR-23000 Zadar, Croatia; E-mail: vbg109@gmail.com or vbabic@unizd.hr.

** Denis Vekić, PhD, Department of Croatian and Slavic Studies at the University of Zadar; Address: Obala kralja Petra Krešimira IV., br. 2, HR-23000 Zadar, Croatia; E-mail: dvekic@ unizd.hr.
} 